\title{
.. THE ANTIBODY CONTENT OF SINGLE CELLS
}

\author{
BY \\ M. C. BERENBAUM \\ From Glaxo Laboratories Ltd., Greenford, Middlesex
}

Quantitative work on antibody production has, from the beginning, been principally concerned with the response of the whole animal, and particularly with measurements of antibody concentration in the serum. The value of such studies is limited when we wish to use the immune response as a tool for investigating protein synthesis or the relation between structure and function of the cell.

The level of antibody in the serum of an animal at any particular moment is the resultant of complex processes of production, fixation to antigen deposits, excretion, and catabolism. Much attention has therefore been given in recent years to the experimental isolation of the antibodyforming process. Use has been made of more or less well-defined cell inocula injected into $x$ irradiated hosts (Roberts and Dixon, 1955; Harris and Harris, 1957; Chase and Wager, 1957 ; Stavitsky, 1958), of lymph nodes transplanted to hypogammaglobulinaemic recipients (Martin, Waite, and McCullough, 1957), and of incubation in vitro of tissue slices or fragments (Askonas and White, 1956; Thorbecke and Keuning, 1956; McKenna and Stevens, 1957 ; Stevens and McKenna, 1958; Askonas and Humphrey, 1958).

To supplement such studies it would be of value to be able to investigate quantitatively the features of antibody production by single cells, including the timing and rate of antibody formation, the turnover of intracellular antibody, and the cell content of antibody.

In this paper an approach is made to one aspect of the matter, a method for measuring the antibody content of individual cells. This work followed on an experiment reported earlier (Berenbaum, 1956). A full account of the technique is being prepared for publication elsewhere.

\section{Materials and Methods}

Immunization.-Rabbits were immunized by repeated injections of human serum albumin that had been precipitated with alum or mixed with an oily adjuvant. Injections were given by multiple routes and some were given subcutaneously into the ears, so that the regional lymph nodes were actively involved in the immune response.

Imprints.-At the fourth or seventh day after the last injection the rabbits were bled out under pentobarbitone. The parotid lymph node was cut and imprints of it made on glass slides. These were fixed in $95 \%$ ethyl alcohol at $37^{\circ} \mathrm{C}$. for 15 minutes, as in the method of Coons, Leduc, and Connolly (1955) for demonstrating antibody by a fluorescein-labelling technique.

Labelled Antigen.-Radio-iodinated human serum albumin, obtained from the Radiochemical Centre, Amersham, was mixed with one-fifth of its volume of $10 \%(\mathrm{w} / \mathrm{v})$ sodium iodide and 10 volumes of normal rabbit or guinea-pig serum. This was then mixed with an equal volume of saturated ammonium sulphate and centrifuged. The supernatant fluid was dialysed against saline at $p \mathrm{H} 7.0$ and $4^{\circ} \mathrm{C}$. until free of sulphate, made up with rabbit or guinea-pig serum to a final antigen concentration of $0.5 \mathrm{mg} . / \mathrm{ml}$. and centrifuged before use. These steps were taken to reduce non-specific surface adsorption of the labelled protein and remove radioactive contaminants.

At the time of use the antigen had a specific activity of $20 \mu \mathrm{C} . / \mathrm{mg}$.

Antibody-labelled Antigen Reaction.-The labelled antigen solutions were applied to the imprints in petri dishes lined by wet filter paper. After an hour the slides were washed in buffered saline for 10 minutes and placed in $80 \%$ ethyl alcohol. .To block the antigen-antibody reaction specifically, $10 \mathrm{mg} . / \mathrm{ml}$. of unlabelled human serum albumin was added to the solution of homologous radio-iodinated antigen.

Autoradiography.-Lajtha's (1954) technique was used. Exposure was usually for two to four weeks at $4^{\circ} \mathrm{C}$. After staining, the slides were mounted in D.P.X. and examined under an oil-immersion objective.

Localization of Intracellular Antibody. - In imprints taken seven days after the last injection of antigen numerous developed silver grains were seen over plasma cells, but not over lymphocytes, granulocytes, mast cells, or reticulum cells, all of which could be easily identified in the stained imprints. Uptake of labelled antigen was blocked by excess of unlabelled human serum albumin. There was no uptake in imprints of animals im- 
munized with heterologous protein antigens or bacterial vaccines or in unimmunized rabbits.

Estimation of Antibody Content per Cell.After exposures of two half-lives (16 days) there were usually between 50 and 150 grains over and immediately around each cell that had fixed the labelled antigen. Occasional cells were seen with up to 300 grains. These figures are necessarily approximate ; it is not possible to make accurate grain counts by visual means alone when there are 100 grains or more over individual cells.

Consider a cell that has produced 100 overlying grains in two half-lives. Since one $I^{131} \beta$-particle produces an average of 7.8 grains in stripping film (Cormack, 1955) and only half the emitted particles enter the film, the number of $\beta$-particles emitted from the cell in this time was $\frac{100}{1.8} \times 2$. In two half-lives three-quarters of the radioactive atoms will have released $\beta$-particles. Therefore the number of $I^{131}$ atoms in the antigen fixed by the cell was $\frac{100}{1.8} \times 2 \times \frac{4}{3}$, or 148 .

One Curie of carrier-free $\mathrm{I}^{131}$ weighs $7 \times 10^{-6} \mathrm{~g}$. (Francis, Mulligan, and Wormall, 1954). Therefore the weight of $I^{131}$ in $1 \mathrm{mg}$. of radio-iodinated human serum albumin with a specific activity of $20 \mu \mathrm{C} . / \mathrm{mg}$. is $7 \times 10^{-6} \times 20 \times 10^{-6}$, or $140 \times$ $10^{-12} \mathrm{~g}$. The number of $\mathrm{I}^{131}$ atoms in $1 \mathrm{mg}$. of

this antigen is therefore $140 \times 10^{-12} \times \frac{6.023 \times 10^{23}}{131}$.

Since 148 atoms of $I^{131}$ were present in the cell, the amount of antigen fixed by the antibody it

contained was $148 \times \frac{131}{140 \times 10^{-12} \times 6.023 \times 10^{23}} \times$ $10^{-3} \mathrm{~g}$., or $2.1 \times 10^{-13} \mathrm{~g}$.

It remains to relate this quantity of antigen to the amount of antibody present. In solution the combining ratio of antigen and antibody depends on their valencies and concentrations, but the position is probably different when one of the reactants is insoluble. Coons et al. (1955) found empirically that fixing in $95 \%$ ethyl alcohol at $37^{\circ} \mathrm{C}$. for 15 minutes made intracellular antibody insoluble without obviously impairing its combining power. In these circumstances the freely diffusible antigen molecules will tend to occupy all the reactive sites on the fixed antibody molecules unless the latter are so closely packed that there is appreciable steric hindrance. If sufficient antigen is present, the antigen-antibody combining ratio will thus depend only on the valency of the antibody. Taking the valency of rabbit antibody as 2 (Marrack, Hoch, and Johns, 1951 ; Plescia, Becker, and Williams, 1952), we may assume for our present purpose that one molecule of antibody (mol.wt. 165,000) has combined with two molecules of human serum albumin (mol.wt. 69,000). The amount of antibody in the cell under consideration is therefore $2.1 \times \frac{10^{-13} \times 165,000}{2 \times 69,000}$ g., or $2.5 \times 10^{-13}$ g. Since between 50 and 150 grains were produced in two half-lives, the amount of antibody per cell ranged from 1.25 to $3.75 \times 10^{-13} \mathrm{~g}$., and in the occasional cell with about 300 grains there were $7.5 \times 10^{-13} \mathrm{~g}$. of antibody.

This is clearly only a first approximation. It is based on the assumptions that all or almost all the intracellular antibody is fixed by the alcohol treatment and that its combining power is not extensively impaired. These assumptions are at present being investigated. The errors they introduce are probably greater than those inherent in quantitative autoradiography. The latter are caused by the random nature of radioactive decay and by variations in the thickness of the autoradiographic film. However, if the assumptions as to the behaviour of alcohol-fixed antibody are not seriously at fault, the amount of intracellular antibody estimated is likely to be of the correct order.

Changes in Antibody Content during Cell Maturation.-When imprints were made four days after the last antigen injection, there was fixation of labelled antigen not only by mature plasma cells (Figs. 1, 2) but also by developing plasma cells and by cells so immature that they could not be identified as belonging to the plasma cell series (Figs. 3, 4). Immature cells had fixed only small amounts of antigen. There appeared to be an increase in antibody content with cell maturation, as maximum antigen fixation was seen only in mature plasma cells.

\section{Discussion}

The specificity of this method for the demonstration of antibody is shown by the fact that positive results are obtained only by treating impi ints from immune animals with labelled homologous antigen: they are not obtained when the animal is unimmunized or immunized with a heterologous antigen. Moreover, the reaction is 

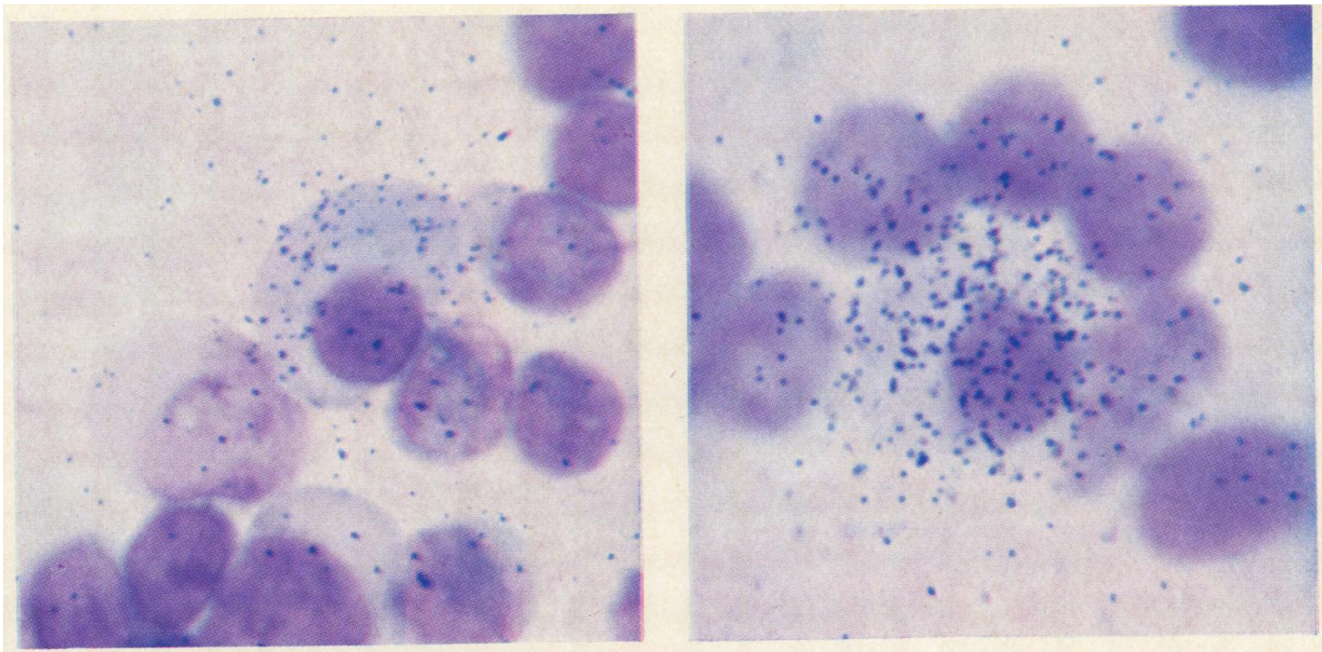

Figs. 1 and 2.-Mature plasma cells.
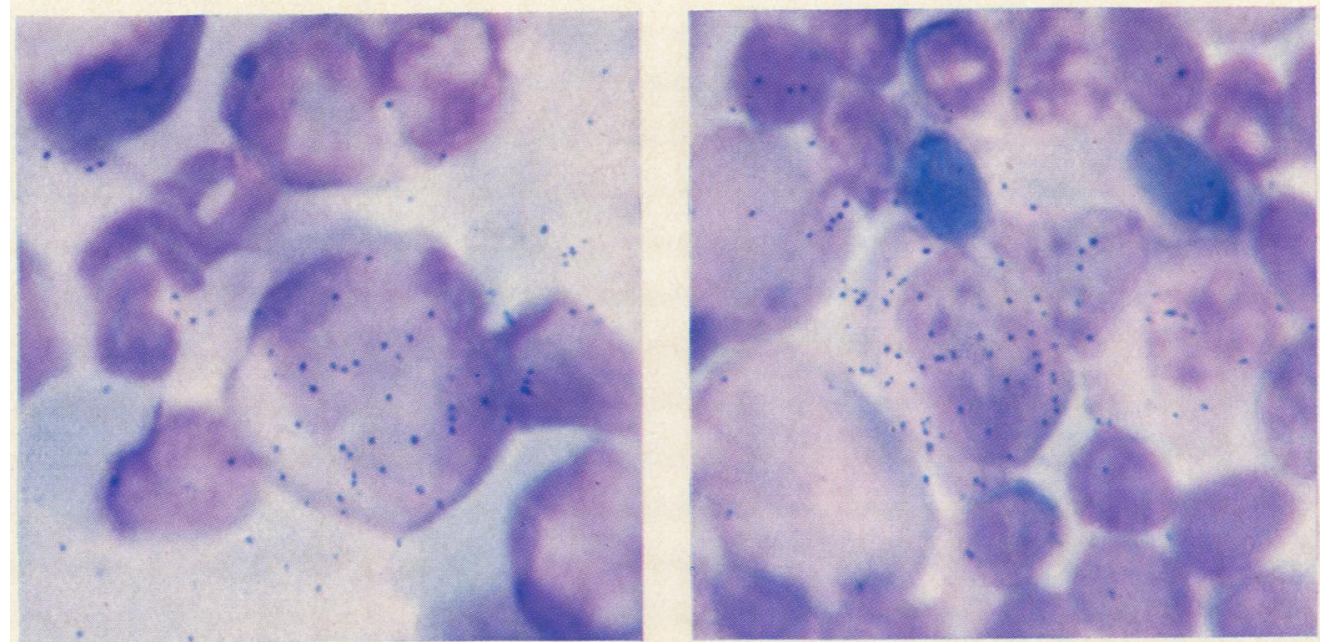

Figs. 3 and 4.-Immature cells.

Autoradiographs of antibody-containing cells in lymph-node imprints from a rabbit immunizod with human serum albumin. Imprints made four days after the last antigen injection and treated with radio-iodinated human sorum albumin. Exposure 28 days. Leishman-Giemsa. $\times 1,700$. 
blocked if excess of unlabelled human serum albumin is added to the radio-iodinated antigen, but not by excess of rabbit or guinea-pig serum proteins.

The finding that the antibody-containing cells are plasma cells accords with a considerable body of evidence that plasma cells contain and secrete antibody (Björneboe and Gormsen, 1943 ; Bing, Fagraeus, and Thorell, 1945 ; Fagraeus, 1948 ; Thorbecke and Keuning, 1953; Coons et al., 1955 ; Askonas and White, 1956).

The primitive cells that appeared to contain small amounts of antibody may have been plasmablasts, or they may have belonged to the lymphoid follicles that, although not containing plasma cells, possibly contribute to antibody formation (Keuning and van der Slikke, 1950 ; Coons et al., 1955 ; Leduc, Coons, and Connolly, 1955 ; White, Coons, and Connolly, 1955 ; Ortega and Mellors, 1957). The answer to this question depends on a more certain identification of cell types in imprints.

Results from three sources permit independent estimates to be made of the amount of antibody in a single cell.

(1) Roberts and Dixon (1955) transferred lymph node cells from immunized rabbits into the abdominal wall of $x$-irradiated recipients. From the rise in serum antibody in the recipients they calculated that each transferred cell had produced its own weight of antibody in about eight days. The weight of an average cell was $250 \times 10^{-12} \mathrm{~g}$., and therefore the rate of production was $30 \times 10^{-12}$ g. $/ 24 \mathrm{hrs}$. Now the amount of antibody produced in 24 hours is equal to the cell antibody content multiplied by 24 and divided by the turnover time. Humphrey and Sulitzeanu (1958) found that the turnover time of rabbit antibody was two to three hours. On substituting these values in the above formula, the estimated cell antibody content works out at 25-37.5 $\times$ $10^{-13} \mathrm{~g}$. This is about 10 times higher than what is obtained by the autoradiographic method, but, considering the unknown factors operative in this, it may not be thought too great a divergence. However, as pointed out by Humphrey (personal communication), although the authors showed that there was no multiplication of cells at the site of injection, they did not exclude migration of donated cells to other sites and multiplication there. Their estimate of antibody production per cell may therefore be too high. It may be noted that Hašková and Mitchison (1958) found that spleen cells from immunized mice, which produce antibody after subcutaneous injection into non- immune hosts, left the injection site after a few days. However, antibody production continued, presumably by cells that had migrated to the regional lymph nodes.

(2) Humphrey and Sulitzeanu (1958) extracted intracellular antibody from the organs of hyperimmune rabbits and usually found about 0.05 $\mathrm{mg}$./g. in lymph nodes. If we may assume that the number of antibody-producing cells in such lymph nodes was $1.0-10 \%$ of the total, then the concentration of antibody in the plasma cells was $0.5-5.0 \mathrm{mg}$. $/ \mathrm{g}$., and the amount in a cell weighing $250 \times 10^{-12} \mathrm{~g}$. would therefore have been $1.25-$ $12.5 \times 10^{-13} \mathrm{~g}$.

(3) Nathans, Fahey, and Potter (1958) extracted the myeloma protein from a plasma-cell tumour of mice and found that it amounted to 1.7-5.4 $\mathrm{mg}$. $/ \mathrm{g}$. of tumour. If we assume that the tumour consisted entirely of plasma cells with an average weight of $250 \times 10^{-12} \mathrm{~g}$., each cell would have contained $4.05-13.5 \times 10^{-13} \mathrm{~g}$. of myeloma protein.

Though results on the production of an abnormal protein by a neoplasm must be of limited relevance to work on antibody synthesis, the broad similarity between the two phenomena and the paucity of other quantitative results to some extent justify their use in this instance. The figures are summarized in the Table, from which it may be concluded that the autoradiographic method, although based on assumptions at present lacking adequate experimental support, is capable of giving a reasonable estimate of intracellular antibody content.

TABLE

ESTIMATES OF INTRACELLULAR ANTIBODY

\begin{tabular}{llll|l}
\hline \multicolumn{3}{c|}{ Source of Data } & & \multicolumn{1}{c}{ Estimate } \\
\hline $\begin{array}{l}\text { Roberts and Dixon (1955) } \\
\text { Humphrey and Sulitzeanu (1958) }\end{array}$ & $\ldots$ & $\ldots$ & $25-37.5 \times 10^{-13} \mathrm{~g}$. \\
Nathans et al. (1958) & $\ldots$ & $\ldots$ & $\ldots$ & $\mathbf{4} \cdot 05-12.5 \times 10^{-13} \mathrm{~g}$. \\
Autoradiographic mothod & $\ldots$ & $\ldots$ & $\ldots$ & $1.25-7.5 \times 10^{-13} \mathrm{~g}$. \\
\hline
\end{tabular}

\section{Summary}

Intracellular antibody may be demonstrated by treating imprints of lymph nodes from immune animals with a solution of radio-iodinated homologous antigen. Uncombined antigen is washed off and autoradiographs are made.

Antibody is present in plasma cells. Grain counts in the autoradiograph over individual cells permit the amount of combined antigen to be calculated. If certain assumptions are made, the amount of antibody per cell may be estimated. 
According to these estimates, plasma cells appear to contain between 1.25 and $7.5 \times 10^{-13} \mathrm{~g}$. antibody per cell.

I am indebted to Drs. J. H. Humphrey and S. R. Pelc for helpful discussions. Skilled technical assistance was given by Mr. W. A. Cope. The photographs were taken by Mr. D. F. Boxall.

\section{REFERENCES}

Askonas, B. A., and Humphrey, J. H. (1958). Biochem. J., 68, 252. and White, R. G. (1956). Brit. J. exp. Path., 37, 61.

Berenbaum, M. C. (1956). Nature (Lond.), $177,46$.

Bing, J., Fagraeus, A., and Thorell, B. (1945). Acta physiol. scand. $10,282$.

Björneboe, M., and Gormsen, H. (1943). Acta patk. microbiol. scand., 20, 649.

Chase, M. W., and Wager, O. A. (1957). Fed. Proc., 16, 639.

Coons, A. H., Leduc, E. H., and Connolly, J. M. (1955). J. exp. Med., 102, 49

Cormack, D. V. (1955). Brit. J. Radiol., 28, 450.

Fagraeus, A. (1948). J. Immunol., 58, 1.
Francis, G. E., Mulligan, W., and Wormall, A. (1954). Isotopic Tracers. Athlone Pross, London.

Harris, T. N., and Harris, S. (1957). Ann. N.Y. Acad. Sci., 64, Art. 5, p. 1040 .

Hašková, V., and Mitchison, N. A. (1958). Nature (Lond.), 182, 410.

Humphrey, J. H., and Sulitzeanu, B. D. (1958). Biochem. J., 68, 146.

Keuning, F. J., and Slikke, L. B. van der (1950). J. Lab. clin. Med., $36,167$.

Lajtha, L. G. (1954). J. photogr. Sci., 2, 130.

Leduc, E. H., Coons, A. H., and Connolly, J. M. (1955). J. exp. Med., 102, 61.

McKenna, J. M., and Stevens, K. M. (1957). J. Immunol., 78, 311.

Marrack, J. R., Hoch, H., and Johns, R. G. S. (1951). Brit. J. exp. Path., 32, 212.

Martin, C. M., Waite, J. B., and McCullough, N. B. (1957). J. clin. Invest., 36, 405.

Nathans, D., Fahey, J. L., and Potter, M. (1958). J. exp. Med., 108, $12 i$.

Ortega, L. G., and Mellors, R. C. (1957). Ibid., 106, 627.

Plescia, O. J., Bocker, E. L., and Williams, J. W. (1952). J. Amer. chem. Soc., 74, 1362.

Roberts, J. C., and Dixon, F. J. (1955). J. exp. Med., 102, 379.

Stavitsky, A. B. (1958). Brit. J. exp. Path., 39, 46.

Stevens, K. M., and McKenna, J. M. (1958). J. exp. Med., 107, 537.

Thorbecke, G.'J., and Keuning, F. J. (1953). J. Immunol., 70, 129.

- (1956). J. infect. Dis., 98, 157.

White, R. G., Coons, A. H., and Connolly, J. M. (1955). J. exp. Med., 102, 73. 